\title{
Comparison Research on the Communication Technology Complex Talent Training Mode at Home and Abroad
}

\author{
Hui Zhang ${ }^{1, a}$, Wenzhun Huang ${ }^{2, b^{*}}$ and Wei Bian ${ }^{1, c}$ \\ ${ }^{1}$ Academic affairs office, Xijing University, Xi'an 710123, China \\ ${ }^{2}$ Departments of Electronic Information Engineering, Xijing University, Xi'an 710123, China \\ a52654708@qq.com, bhuangwenzhun@xijing.edu.cn, c21443022@qq.com
}

Keywords: Home and abroad; Communication technology; Complex talent; Training mode.

\begin{abstract}
In this paper, we conduct research on communication technology complex talent training mode at home and abroad. In order to adapt to the development of modern science and technology, training to adapt to the production, construction, management and service first line need to moral, intellectual, physical, beauty and other aspects of comprehensive development of higher technology applied talents, the higher education must carry out the reform of the teaching methods and teaching means, reform the traditional teaching method, extensively absorb and apply modern teaching means. Education teaching methods and teaching means reform is the basis of teaching reform, is to cultivate students' innovative spirit and practice ability and learning ability, the effective ways is the necessary guarantee to improve the teaching quality. Our article combines the advantages of the communication technology complex talent training mode at home and abroad to propose the novel paradigm which will enhance the effectiveness of our current research condition.
\end{abstract}

\section{Introduction}

The development of higher education to better meet the needs of economic and social development of high-quality innovative talents, the current one of the keys is to improve teaching quality of colleges and universities. Quality is the lifeline of colleges and universities. In some colleges and universities in recent years gradually develop the interactive teaching to improve the teaching quality of colleges and universities are playing an increasingly important role. To cause the attention of people on the basis of summarizing the practical experience to explore the characteristics and law of the interactive teaching, problems existing in the comb and seeking to improve method is a very meaningful work.

According to the review, the primary solutions of the current teaching and training mode could be generally summarized as the following aspects. (1) Problem-based teaching method. Problem-based teaching method is helpful to arouse the learning enthusiasm of students, deepen the understanding of the theoretical knowledge and grasp, beneficial to the improvement of the students' comprehensive quality, also is helpful for teaching is learning. Aim to cultivate students' clinical thinking ability, improve the teaching quality of cardiovascular internal medicine conclusion of experimental group students clinical thinking ability, the ability to analyze and solve problems is higher than the control group. (2) Intuitive teaching method. Intuitive teaching method is to use and with the aid of physical objects, pictures, models, samples, language teaching method and so on carries on the concrete image. It can make the abstract theory of visualization, the static change to mobilize the students' interest in the learning steps to deepen the understanding and the memory to strengthen the visual effect. (3) To explore try teaching method. Inquiry-based classroom teaching especially attaches importance to developing students' creative thinking, train the ability of self-study, tries to guide the student to learn through self-inquiry learning and mastering scientific method, lay the foundation for lifelong learning and work. (4) Interactive teaching method. To carry out the basic interactive teaching method, we can overcome the blindness with fully mobilize students' enthusiasm and initiative. For example, we put 
the reform of the higher mathematics. The teacher put the emphasis and difficulty. Students through self-preparation, find extra-curricular, extra-curricular discussions and other ways to solve problems independently. (5) Multimedia based teaching method. Enrich and develop the teaching means and teaching content, multimedia teaching courseware is one of the effective methods, use of multimedia teaching in class, visual impact and auditory impact to let the students in the classroom better accept knowledge, enhance understanding, deepen the impression, greatly enrich the classroom knowledge capacity, enrich the teaching means make the classroom teaching on the melody vividly ceaselessly, which arouse the student interest and improve the learning efficiency and teaching effect.

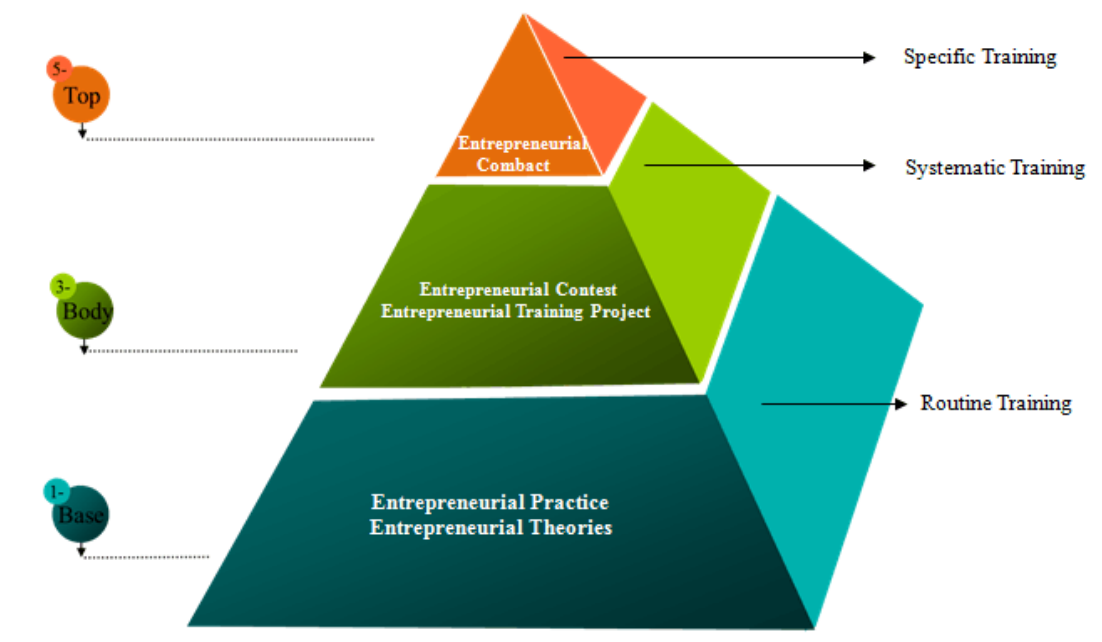

Figure 1. The Primary Components of the Talent Training System

As shown in the figure one, we demonstrate the primary components of the talent training system. Different from industrial economy, knowledge economy is based on knowledge and information of the production, distribution, dissemination, and use as the basis. The development of the knowledge economy puts forward new requirements to the informationization talented person. From a strategic height, therefore, train and bring up a large strain capacity, high level and high quality information talent has become our country under the background of globalization to realize national strategy and the strategic need of the great rejuvenation of the Chinese nation. In the later sections, we will analyze the issues from the perspectives of at home and abroad [1-3].

\section{Our Methodology and Perspectives}

The Domestic Information Technology Teaching Methodology. We are in the information age. Informationization is the trends of world development, is the national trend of social development, the informationization level has become the measure of a national modernization level and the important indicator of overall national strength. Education informatization is the important foundation of the national social informatization construction. The teaching information itself is system, complete that need long-term planning and design which can be achieved. College teaching informationization development need to rely on the support of the national policy and social resources to assist to more perfect. In the process of teaching information for promotion, the diathesis of teachers and students, teaching informatization policy and system and its management measures should be comprehensive consideration and the planning. From the survey results, the primary challenges for the information technology teaching methodology could be summarized as the follows.

- The single talent training mode. Today's stage of popularization of higher education is higher education, the popularization of higher education will not be able to use a pattern to cultivate 
students, and it should be diverse, this way can made students better to the society, to better meet the needs of social development and work [4].

- Students lack of practical ability and innovative spirit. At present, the teaching more focused on imparting theoretical knowledge and book knowledge, the main channel or the classroom teaching, to the cultivation of students' practice ability and innovation spirit enough attention, therefore, cultivating the students' quality and ability is not high.

- We need to update the teaching contents and teaching method. The continuous development of social and economic of talent more higher requirements are put forward. It is pressing for colleges and universities take effective measures to further deepen the teaching reform. In a timely manner to adjust the teaching content, update the teaching means to improve the ability and level of talent training, to better meet the needs of economic and social development of the high-quality innovative talents.

- Professional setting and structure is not reasonable. For some university with a long history, the phenomenon is particularly serious. Some old subject stagnation, it will bring to declare new professional barriers that restrict the development of colleges and universities.

Implementation of the colleges and universities teaching management informatization, which is beneficial to improve the efficiency of teaching management and quality as information is important foundation of modern management and leadership decision-making, the use of information highway, satellite communication technology, computer multimedia technology, network technology and other modern information technology can realize the information in the form of cheap, fast real-time and accurate information transmission and communication, and release all kinds of the information. In addition, the information also can break through the limitation of time and space, such as through the computer network, can put the school teaching management departments at all levels is an organic whole repeatedly, teachers, students, also can make the school and the competent department, other universities, and other social departments together to achieve fast and accurately to upload.

The Information Technology Teaching at Abroad. At present, many colleges and universities in our country in order to reform the teaching mode, adopt the method of combination education to cultivate, some foreign teachers from famous universities abroad for undergraduate and the graduate students teaching, tries to introduce teaching model of foreign well-known colleges and universities directly classroom in the colleges and universities, organized by the foreign well-known university professors lecture and the whole course of lecture, the effect of the practice shows that this way is very good. In the next section, we will introduce the corresponding approaches in different countries.

- Germany. According to German institutions of higher learning education legislation, whether public or private that has the right to implement self-management, but the states competent department of the supervision, which adopted the policy of separating the academic and the non-academic affairs. The vast majority of private colleges and universities in the country did not use the board system [5-6].

- The United States. Private colleges and universities in the United States, in addition to set up a council of professor will also has the school level, the school each department head and dean, professor, director of the institute and representatives of several people. Professor will main function is responsible for the school's teaching and scientific research.

- The French. France has a long history of higher education. The Renaissance higher education obtained the rapid development in the meantime and there are many humanities colleges and college of science and technology that set up later with the development of social, economic, and military and constantly strengthened and perfected. French higher education structure is complex, and other system of higher education in the European and American countries have many differences. France's institutions of higher education are given priority to with public university, private university for a relatively small proportion. 
Teaching mode is a reflection of the teaching thought and teaching law, its specific provision in the teaching process teachers both sides of the activities, teaching program, should follow the principles and the matters needing attention that is the guide of teachers and students both teaching and learning activity. At present, the most influential network teaching abroad is large-scale network open courses, as a new type of "paying equal attention to teaching" teaching mode, the characteristics of the MOOC is massive students interactive participation and open access resources, based on the network and traditional network course, MOOC, textual material, and in addition to providing the video resources online FAQ that also provide learners with a user interactive community, establishing the interactive participation mechanism. Learners only need a computer with an Internet connection we can anytime, anywhere learning all over world famous universities, classroom interaction with tens of thousands of the students online which is more efficient and effective.

The Comprehensive Teaching Approach. Innovative talents of science and technology not only quality of relationship between the science and technology talent team construction, to implement the construction of the human resource and the strategic target of constructing innovative countries have important influence. The corresponding requirements for the education mode could be generally list as the follows. (1) Principles of accuracy. Information elements selection and Settings must seize the essential characteristics of creative talents and use less as far as possible and accurate the information elements to express the content of the evaluation. Information elements of the design of system should have very strong logical relationship between various elements, rather than the accumulation of the various elements. To achieve such a request, which must be repeated verification of the collected information, constantly testing that makes every effort to reduce the error to a minimum. (2) Scientific principles. Elements of information system design must be based on science, on the basis of elements of the definition, connotation clear, convenient calculation method to, at the same time, combined with the necessary special investigation and research, combining qualitative and quantitative, tries to comprehensively and the objectively reflect and describe the innovative talents. (3) Overall principle. This principle requires extensive, information collected by a full and complete. Only the broad and comprehensive information can fully reflect the management activities and decision-making object development provide guarantee for decisions more scientific. (4) Timeliness principle. The use value of information depends on whether the information can be provided in a timely manner, namely its timeliness. Information provides users with timely, quickly can effectively play a role. (5) Operability principles. Operational and elements of elements of information system of measurability is building elements of information system is a basic principle with data to have stronger availability.

Electronic communications industry human capital management include primary human resource planning, human resources, attracting, hiring, training, career planning, performance evaluation, the evaluation of investment income, its aim is to make its have to maintain the high value-added human capital and can long to keep the performance level of employees, now the main driving force of the development of the electronic communications industry from the industry of human capital [7].

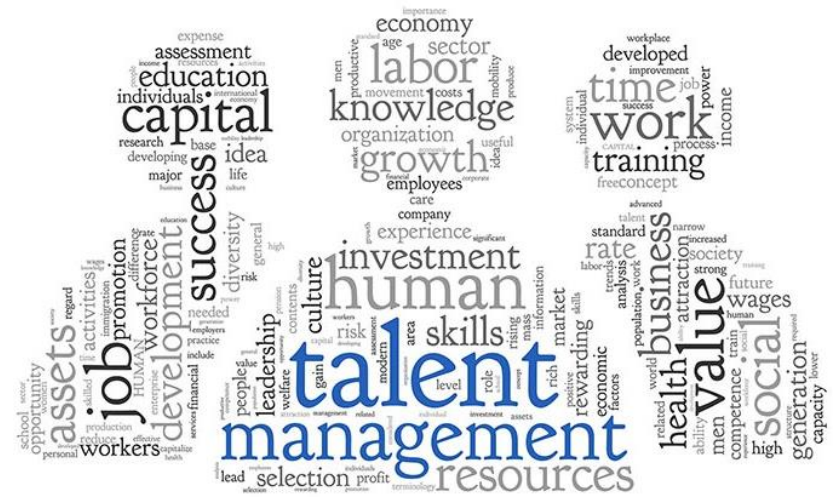

Figure 2. The Keyword of the Comprehensive Teaching Approach for Communication Technology 
According to the keywords provided in the figure two, we could obtain the optimal education form from the listed parts. (1) Establish and perfect the system of the talent market information technology industry. Set up and improve talent market information industry system, speed up the development of information industry professional and technical personnel, enterprise management talents market, to formulate relevant laws and regulations, to ensure the talent flow and the talent market management orderly. (2) Set up information technology industry system of national reserves and the development and utilization of high-end talent and talent internationalization project. Establish a talent agency, exchanging and information industry is the key point of the development of the industry, shortage, weak professional, the introduction of the senior professional technical talent and have a background international operation management talent. Positions open recruitment related international first-class talents, scientific research projects and major projects to attract talented people, to start the funds to attract the potential young talent. (3) Setting up to encourage the rational flow of trained personnel information technology industry platform. Guide all kinds of innovative talents, senior professional and technical personnel and management talents and practical talents to focus on the professional, technical innovation and cluster key development project, to achieve the optimal allocation of human resources and position requirements [8]. (4) The top-level design. It will be a new generation of the information technology industry to develop the innovative entrepreneurial talent training into national development strategies. For the colleges and universities, research institutions, enterprises and social organizations, such as training subject, provide the corresponding training qualification eight, degree awarding, the business license, preferential policies, etc. (5) Set up the comprehensive talented person and create a talent competition. Widen our sight and set up the comprehensive talented person, the introduction of the competition mechanism, in the field of the broader and wider open environment to absorb all kinds of the high level talents, efforts to create a fair competition, merit-based selection, entrepreneurship that as owning good environment.

\section{Conclusion and Summary}

In this paper, we conduct research on the communication technology complex talent training mode at home and abroad. Colleges and universities as the talent cultivation and gathered at the center of the modern society, each year to provide society with a lot of computer professional knowledge and the application ability of talented person. Therefore, university computer course setting is very important to cultivate the student's ability of computer. At present, many colleges and universities in our country in the Settings of the computer courses still lacks scientific, heavy theory teaching, practice teaching to cultivate the talents cannot accord with the requirement of the modern society. To deal with the mentioned challenges, we propose the comparison research between China and abroad countries to form the better connection of teachers and students that will be meaningful.

\section{Acknowledgements}

This research was financially supported by the 2015 Research Project of Higher Education Reform in Shaanxi (15BY126) and the 2015 Teaching Reform Research Planning Project of Xijing University (JGGH1511).

\section{References}

[1] Q. Y. Zhang: 2014 2nd International Conference on Education Technology and Information System (Jinan, China, April 26-27, 2014), p.430. 
[2] H. Zhou: 2nd International Conference on Soft Computing in Information Communication Technology (Taipei, Taiwan, May 31-June 01, 2014), p.272.

[3] J. J. Lin, H. T. Pu, M. Q. Fan, et al: 2nd International Conference on Teaching and Computational Science (Shenzhen, China, July 29-30th, 2014), p.203.

[4] J. P. Dai: Journal of Chongqing University of Posts and Telecommunications (Social Science Edition), Vol. 0 (2013) No.3, p.127.

[5] H. Wang and Y. Yu: Value Engineering, Vol. 32 (2013) No.2, p.240.

[6] J. M. Wu, S. C. Hu, S. P. Li, et al: Science and Technology Management Research, Vol. 32 (2012) No.2, p.166.

[7] L. F. Chen and W. Zhang: Journal of Chongqing College of Electronic Engineering, Vol. 23 (2014) No.4, p.90.

[8] Z. X. Gong and Y. Zhao: Journal of Architectural Education in Institutions of Higher Learning, Vol. 23 (2014) No.2, p.8. 